\title{
Blockholding and organisational diversity: the case of a transition economy*
}

\author{
Janez Prašnikar, Dragan Mikerević, Damjan Voje
}

We approached the issue of blockholding effectiveness and behaviour by studying some exemplary organisational transformations in the Republic of Srpska. We found two distinct clusters of blockholdings. The first cluster is workerentrenched blockholdings, where most workers are unionised. The second cluster constitutes worker-liberal blockholdings, where most workers are not unionised. There are two distinct subgroups in this cluster. The vast majority of blockholdings in the first subgroup developed a prevailing role of the capital owner, heavyweight management and a less trained workforce. The second subgroup nurtures reciprocity of management and core workers' cognitive assets, and is also the most productive.

Wir haben die Wirksamkeit und das Verhalten von Großaktionären anhand von organisationalen Transformationen in der Republik Srpska erforscht. Wir entdeckten zwei verschiedene Gruppen von Großaktionären. Die erste Gruppe besteht aus fest verwurzelten Arbeiternehmer-Großaktionären, wobei die meisten Arbeitnehmer gewerkschaftlich organisiert sind. Die zweite Gruppe umfasst liberale Arbeitnehmer-Großaktionäre, wobei die meisten Arbeiter nicht gewerkschaftlich organisiert sind. Es gibt zwei verschiedene Untergruppen in dieser Gruppierung. Die große Mehrheit der Großaktionäre in der ersten Untergruppe entwickelte eine dominante Rolle der Kapitaleigner, ein starkes Management und weniger gut ausgebildete Arbeitskräfte. Die zweite Untergruppe fördert die Wechselwirkung zwischen dem kognitiven Vermögen von Management und Kernarbeitern und stellt zudem die produktivste Gruppe dar.

Key words: corporate governance, organisational transformation, developing countries, blockholding, worker empowerment (JEL: J54, P20)

\footnotetext{
* Manuscript received: 22.8.12, accepted: 3.8 .13 (2 revisions)

** Janez Prašnikar, Faculty of Economics, Institute for South-East Europe, University of Ljubljana and CEPR. Main research interests: firm level productivity, internal bargaining, corporate governance, self-management and participatory firms in developing economies. E-mail: janez.prasnikar@ef.uni-lj.si Dragan Mikerević, Faculty of Economics, University of Banja Luka. Main research interests: strategic financial management, business finance and accounting, firms` post-transitional behaviour, enterprise valuation. Damjan Voje, Faculty of Economics, Institute for South-East Europe, University of Ljubljana. Main research interests: microeconomics, corporate governance, firm behaviour, intangibles, social capital.
} 


\section{Introduction}

Blockholding, or concentrated ownership in the hands of one single owner or a few large owners, has been in the focus of corporate governance research (Holderness 2003). ${ }^{1}$ Studies have shown mixed results about the role of blockholdings in corporate governance subject to organisational development. Is it a substitute for legal protection in institutionally poor environments (Shleifer/Vishny 1997; La Porta et al. 2008), or is it a foundation for strategic coordination between different stakeholders (Black 1990; Cronqvist/Fahlenbrach 2009)? Most research so far has come to the conclusion that concentrated ownership affects firm performance positively (Tribo et al. 2007) due to easier long-term goal orientation agreements (Hoskisson et al. 2002) and more intense monitoring of managers' actions, consequently decreasing managerial discretion and inhibiting self-serv-ing behaviour (Finkelstein/Boyd 1998; Tosi et al. 1997). However, there are also studies showing negative effects of blockholding on firm performance due to decreased liquidity of equity (Maug 1998), misguided corporate strategic alignment (Thomsen/Pedersen 2000) or deriving benefits from the control function only for the largest blockholder (Johnson et al. 2000; Dyck/Zingales 2004). So a question arises: What differentiates the effectiveness of block-owned firms? We approach this issue by studying the affect of labour market institutions.

While there is convincing evidence about the influence of labour institutions in Western Europe on the effectiveness of a blockholding (Henrekson/Jakobsson 2012; Van Essen et al. 2012), there is much less evidence from transitional countries. In particular, there is almost no information from countries of the former Yugoslavia, where peculiar labour relations, including worker participation, played an important role in the past. ${ }^{2}$ After Yugoslavia fell apart in the last decade of the 20th century, new countries have emerged in its place. Among them, Bosnia and Herzegovina has had the most dramatic history.

\footnotetext{
The term blockholding (and blockholders) is commonly used in economic literature, dealing primarily with the problems arising from more/less concentrated ownership and agency problems (see Holderness 2003). Blockholding refers to a situation of having large owners present, whereby the limits to what is large are set differently. For example, Demsetz and Lehn (1985) suggest using largest 5 to 20 shareholders, while Schleifer and Vishny (1986) suggest a 5\% limit (in Earle et al. 2005). The notion of a block refers primarily to the "power to impact" therefore the definition can differ by country (institutional characteristics) or industry. Type, size and number of blockholders matters for firm structure, strategy and long-run performance (see Tribo et al. 2007; Sanchez-Ballesta/Garcia-Meca 2007; Henrekson/Jakobsson 2012).

2 Damijan et al. (2004) revealed raising ownership structure concentration in Slovenia as a result of the battle for control between blockholders, which is negatively influencing corporate performance. Koman et al. (2013) describe the appearance of blockholdings in Montenegro in relation to stripping assets in the privatisation processes when interdependency between economic actions and political positions of individuals did not lead to establishing rules which would promote value building.
} 
Our research is based on a questionnaire study that was conducted in autumn 2011 in the Republic of Srpska, one of the entities constituting Bosnia and Herzegovina. In the recent decade the country has been strongly influenced by economic reforms on account of privatisation, liberalisation, and a changing global environment (globalisation). Mass privatisation was introduced in the years 2000 and 2001 with the intention of making ownership dispersed in most privatised companies. The country preserved Yugoslav labour relation institutions for a long time and in the year 2000 adopted a liberal Labour Law to ease some of the labour market rigidity.

In our case, we are dealing with a unique database of companies where top managers were asked specific questions about relations between corporate stakeholders (owners, managers, and workers) and corporate governance. Our study has two main findings: First, in the period of ten years after the liberal reforms were launched, blockholding became the prevailing ownership structure in the Republic of Srpska. Second, significant differences in the behaviour of blockholdings based on the empowerment of workers are observed. We identified two distinct clusters of firms. In the first cluster most workers are institutionally empowered (unionised), therefore we call these firms 'Worker-Entrenched blockholdings'. Although cooperative behaviour between the blockholders and unions is evident in few cases, there are also signs of rent-seeking behaviour of unions, who use their monopoly position in order to expropriate a part of value added. This is particularly evident in some state-owned firms.

The second cluster of firms shows a different pattern of development. We named these firms 'Worker-Liberal blockholdings', since most workers in this cluster are not institutionally empowered, but rather present an unconstrained work force in the labour market. There are two distinct subgroups in this cluster of firms identified as well. A vast majority of blockholdings in the first subgroup correspond to a profit maximising Core-Periphery mode of firm with a prevailing role of the capital owner, heavyweight management and a less trained workforce. The second subgroup strongly reflects the Reciprocal-Essentials (hereafter RE) mode of firms (Aoki 2010), where the main ingredient of such mode is the growing importance of human cognitive assets, not limited only to those of management but also including those of core workers. Hence, the blockholding diversity appears as the result of different labour relations in firms and various types of corporate governance could be found.

Our contributions are threefold. First, we contribute to the literature on blockholdings by analysing blockholdings' corporate behaviour and organisational architecture in the framework of different labour institutional arrangements (Wright et al. 1996; Holderness 2003; Sanchez-Ballesta/Garcia-Meca 2007; Edmans 2009). Second, by studying firm behaviour in one ex-Yugoslav-ian country, we are able to shed light on the transformation of labour capital relations and corporate governance after the abandonment of social ownership and 
worker's self-management. Thus, our analysis of blockholdings in the Republic of Srpska also portraits well the development of corporate governance in other parts of former Yugoslavia. On this ground we contribute to the emerging comparative view of corporate governance, which seeks to explain corporate governance both in terms of agent relations and path (national) dependency (Hall/Soskice 2001; Aguilera/Jackson 2003; Hopner 2005; Aguilera et al. 2008; Aoki/Jackson 2008; Aoki 2010). Third, we made methodological innovations in the approaches to surveying organisations.

In the following section we present the development of blockholdings in the Republic of Srpska as well as describe the labour market to embed the evolution of blockholding into context. In the third section, we present the hypotheses of our research. This is followed by methodology along with the survey design and questionnaire structure. In the fifth section we convey our results. In the last section we draw conclusions.

\section{Development of blockholdings and specific labour institu- tions in the Republic of Srpska}

\subsection{Economy of the Republic of Srpska}

The disintegration of Yugoslavia in the 1990s had a strong effect on the Bosnian economy. The armed conflict that followed on its territory destroyed a substantial part of its physical and human capital. In 1995, the Dayton Accord split the state of Bosnia and Herzegovina into separate entities: the Federation of Bosnia and Herzegovina (Federation), the Republic of Srpska, and Brčko District.

In the period from 2000 to 2008, Bosnia and Herzegovina witnessed robust growth, in particular a double-digit GDP nominal growth rate and a real growth rate between $6 \%$ and $7 \%$. The growth was stimulated by international assistance, increased foreign and domestic investments, a credit boom funded by foreign banks and booming domestic demand financed from abroad. While residents in all Balkan countries spent more than they earned from domestic sources, the Republic of Srpska boasted some of the highest ratios of domestic absorption over GDP. This was possible mainly by large remittances from family members working abroad. According to the estimations, those transfers generate between $15 \%$ and $18 \%$ of GDP every year (EBRD 2011).

After several years of growth, the economy experienced a sharp decline in the late 2008, similar to the case of other countries in the region. The output also fell significantly in 2009 by approximately $3 \%$ (EBRD 2010). This economic downturn settled slightly in 2010. However, in 2011 the economy of Bosnia and Herzegovina stagnated and remains in deep recession. The trend of negative developments persisted in 2011 in the field of foreign direct investments, budget deficit, increased cost of living, rising inflation and a constant increase in unem- 
ployment. In 2011, the number of employed people in Bosnia and Herzegovina amounted to 693,359 , while the number of unemployed people was 529,994 (in 2010 there were 517,004 unemployed). In the Federation of Bosnia and Herzegovina, the number of employed people was 441,115 , while 367,512 were unemployed. In the Republic of Srpska, there were 239,998 employed and 150,971 unemployed. The employment rate in Bosnia and Herzegovina was 31.9\% (29.8\% in the Federation of $\mathrm{BiH}, 36.1 \%$ in the Republic of Srpska, and $22.9 \%$ in the Brčko District), and the unemployment rate was $27.6 \%$ (29.2\% in the Federation of $\mathrm{BiH}, 24.5 \%$ in the Republic of Srpska and 39\% in the Brčko District). According to the ILO methodology, the unemployment rate in Bosnia and Herzegovina was $27.6 \%$ in 2011, compared to 2010 when it was $27.2 \%$ (Stanković 2012).

\subsection{Ownership concentration}

A proper legal protection of investors, including minority investors (shareholders and creditors), ownership disclosure and transparency, and capital market transactions are determined within the legal framework of each entity. With assistance from the international community, the Federation of $\mathrm{BiH}$ and the $\mathrm{Re}-$ public of Srpska adopted commercial legislation and the Company Act. The Federation of BiH adopted the Company Act in 1998, and the Republic of Srpska in 1999.

Discussions about the best privatisation model followed the overall debate on corporate governance in Bosnia and Herzegovina, especially on how to find the most efficient way of transmitting the interests of owners to the company. The entities adopted mass privatisation as the prevailing privatisation programme in hope that ownership in most companies would end up dispersed. ${ }^{3}$ There were three approaches used: privatisation of small companies - small privatisation, the privatisation of large companies - large privatisation, and the privatisation of strategically important companies. The assets of companies undergoing privatisation could be purchased with cash, vouchers or coupons. ${ }^{4}$

The privatisation started with a pilot programme of hard currency auctions in 18 small companies (coupons were treated as hard currency) in July 1999. By March 2001, 98 of 276 small companies had been sold for a total value of KM 20.6 million (approximately 10 million Euros), of which about $80 \%$ was paid in coupons.

This was a prevailing view in most transitional countries. As argued by Hansmann and Kraakman (2001), the best form of an organisation is the shareholder-oriented model, and practice and law are convergent on this model.

4 Each citizen in the Republic of Srpska was entitled to vouchers, while coupons were issued on the basis of frozen foreign account deposits. Vouchers could only be used in privatisation through the voucher offer, and were valid for two years after they had been deposited into a special Privatisation Account. 
Approximately 600 companies in the Republic of Srpska that hold around onequarter of the total assets of state-owned enterprises were subject to privatisation under the voucher privatisation scheme from the year 2000 to 2001 (IMF 2005). The first official trade in Bosnia and Herzegovina took place on March 14, 2002 on the Banja Luka Stock Exchange in the Republic of Srpska. Even though there were some successful examples of privatisation, the general effect of voucher privatisation was minor, accompanied by few new investments and a notable lack of skills of leading managers (OHR 2004).

Out of the 135 strategic companies, 52 of them were selected for the privatisation in the framework of international tenders. However, in the first years only a small number of strategically important companies was sold through auctions and international tenders. Therefore, after 2003 there was more focus on the privatisation of strategically important companies. The Republic of Srpska sold some of its most attractive assets to foreigners between 2004 and 2007. In the period from 2005 to 2006, the manufacturing and banking sectors attracted most of the foreign bidders. The main telecommunications company was sold in 2007. This was by far the largest foreign investment in the Republic of Srpska in the last decade. In the period from 2008 to 2010, the most important sector was the retail sector

Consequently, since the beginning of privatisation the share of the Republic of Srpska's state ownership has greatly diminished. However, some companies remain in direct state ownership. The state also holds a prevailing share in some joint corporations. A number of firms were privatised to foreigners. The remaining forms of corporations are privately owned corporations, which arose from the voucher privatisation programme. Today, most of the voucher-privatised firms exhibit enormous difficulties in corporate governance and are, in many cases, captured by influential groups or individuals (Hoff/Stiglitz 2004; Koman et al. 2013). Taking also into account newly established firms by private entrepreneurs, blockholding is currently considered to be the dominant corporate governance mode in the Republic of Srpska (Mikerević 2012). ${ }^{5}$

\subsection{Industrial relations}

The labour legislation in Bosnia and Herzegovina, social dialogue and collective bargaining are displayed at the level of entities. Even though laws have been designed and passed in Parliaments of the entities after the war, they retained rigid clauses and inflexibility within the labour market remained. Under pressure from the international community, both entity governments have amended labour laws. The Labour Law in the Republic of Srpska, which was amended in

Data on the exact share of private domestically-owned firms vs. private foreign-owned firms vs. state-owned firms in the Republic of Srpska is impossible to obtain due to the constantly changing number of firms (bankruptcies, liquidations, mergers, new entry) and a prevailing number of small firms with less than 20 employees. 
November 2000 (Službeni Glasnik, RS 38/00, 40/00, 41/00), eased some of the labour market rigidities. The notice period and the size of severance paid by employers were both significantly reduced. In this sense, labour legislation in the Republic of Srpska is relatively liberal.

Any worker that is employed can become a member of the labour union, whereby he/she accepts the rights and obligations arising from the Statute and other acts of the labour union. There is currently no official data that could accurately indicate the actual share of employees as union members. According to some estimates, approximately one-half of employees in $\mathrm{BiH}$ are members of labour unions (Dedic 2013). There is higher labour union presence in the public sector. In the private sector, labour unions are most frequently present in those companies that had labour unions organised before they had been privatised, while it is seldom the case in newly established private companies that employers would allow their workers to engage in union activities (Stanković 2012).

The Association of Unions of the Republic of Srpska ${ }^{6}$ is a representative and the carrier of collective bargaining in the Republic of Srpska, together with the government of the Republic of Srpska and Union of Employers of the Republic of Srpska (Unija udruženja poslodavaca Republike Srpske) (Službeni Glasnik, 2007). ${ }^{7}$ In May 2010, they jointly signed an 'umbrella' General collective agree-ment, which set the rules for determining basic wages. Basic wages are determined by multiplying the initial wage for the simplest work task with the so-called coefficients, each representing particular weight for more demanding work tasks. The minimum wage in the Republic of Srpska is set forth by the General collective agreement as well. The General collective agreement is supplemented by industry-specific agreements or special agreements that are uniting a few industries, which effectively convert the concept of basic wage on the level of industries or groups of industries. Four industry agreements and six special agreements are currently in effect in the Republic of Srpska. In addition to sizes of coefficients for different occupations, they also differ in the context they cover. For example, the collective agreement for the energy sector has (along with the finance sector) the highest minimum wage and coefficients for classifying wages based on specific tasks. The General collective agreement applies to all workers and employers. No collective agreement concluded at the branch or company level may grant lesser rights than those stipulated in the General Col-

\footnotetext{
6 In 1992, the Association of Unions of the Republic of Srpska (Savez sindikata Republike Srpske) was founded. The Association was formed from the organisation "Zveza sindikatov Jugoslavije" (Association of Unions of Yugoslavia). In addition to union organisations, which operate under the auspices of the Association, there are also enterprise unions in some companies, which are not members of the Association. They emerge spontaneously, in the event that employees are dissatisfied with the operation of the official Association, which is particularly the case in bankrupted companies. Currently, they have no great significance.

7 In addition to collective bargaining a, tripartite social dialogue is organised through of the Economic and Social Council which involves the representatives of the Government of the Republic of Srpska, Association of Unions of the Republic of Srpska and Union of Employers of the Republic of Srpska.
} 
lective Agreements. The differences between the public and private sector are especially evident in the area of implementing the existing collective agreements, where provisions of agreements are more frequently violated in the private sector (Stanković 2012).

The Labour Law completely excludes the participation of employees in corporate governance, i.e. it does not propose or prohibit workers' participation. The employer is only obligated to inform employees about their rights and obligations, wages, the state of the company, and future development. As for employees' councils or workers' councils, the entity laws regulate their organisation. In order for the workers' council to be formed, the employer must have at least 15 workers in permanent employment position. In the Republic of Srpska the decision on the establishment of a workers' council can be made by no less than one-third of the total number of workers at a single employer (Stanković 2012).

\section{Related literature and hypotheses}

The paper refers to the literature on corporate governance. In the leading agency -theoretical explanation of corporate governance (Jensen/Meckling 1976; Fama 1980; Fama/Jensen 1985), ownership and control are dispersed and stock markets are liquid, generating higher returns, providing higher possibilities of diversification for investors and facilitating financing to managerial entrepreneurships (the outsider system). On the other hand, the blockholding system (the insider system) is a system of large shareholders (blockholders). It ensures more vigilant shareholders' monitoring over management and longer shareholders' time horizon. Capital markets are thinner than in the outsider system and the liquidity of stocks is rather low (Bratton/McCahery 2002; Holderness 2003). While the advocates of the outsider systems see blockholdings as a substitute for legal protection in a poor environment (Schleifer/Vishny 1997; La Porta et al. 2008), the opponents claim that blockholders are common all over the world and seem to be relatively stable in time (Holderness et al 1999, Holderness 2003). Moreover, there is an emerging view on corporate governance (Hall/Soskice 2001; Aguilera/Jackson 2003; Aguilera et al. 2008; Aoki/Jackson 2008; Hopner 2005) that seeks to explain corporate governance both in terms of agent relations and path (national) dependency.

The paper also refers to the literature on labour unions and bargaining. The more recent models, taking into account the bargaining process between management and unions, replaced traditional perceptions of unions as a monopolist on the supply side of the labour market. The notion of bargaining assumes that unions have control over employment as well as wages. Different strategies are then possible. Monopoly unions could maximise a wage bill and choose a level of employment where marginal wage equals zero, or they maximise the markup of wages over the market (alternative) wage. The equilibrium wage is higher in the latter case (maximisation of rents) than under wage bill maximisation 
(Ehrenberg/Smith 2011). The monopoly union model presupposes that bargaining between managers and unions is sequential, with unions setting and then the firm choosing the level of employment. However, if the values of those variables are chosen simultaneously, this results in a situation of efficient bargaining (Estrin et al. 2008). The formal models of efficient bargaining take a game theoretical approach and search for a solution on the contract curve, the locus of points on the firm's labour demand curve and the union's indifference curve. The precise point on the contract curve chosen by the two sides depends upon their relative bargaining power. As the bargaining power could be an exogenously determined force, the outcome depends not only on endogenous, but also on exogenous factors (Svejnar 1986). In particular, European countries feature rather specific institutions in regard to the role of labour in the economy and corporate governance (Ferner/Hyman 1998). Van Essen et al. (2012) investigated if European labour institutions can function as a countervailing power to blockholdings and even increase the cooperative capabilities of shareholders and their willingness to cooperate with workers to increase profit. They identified the following influences of labour institutions on blockholding: 1) the employment protection laws constrain the ability of blockholders to pursue value-enhancing adjustments of the scale operations in their firms; 2) collective labour action laws negatively affect blockholder effectiveness; 3) employee involvement in firm decision-making has a positive effect on blockholder effectiveness, and 4) no significant effect of the level of unionisation on blockholder effectiveness exists.

Whereas the negative effects of employment protection and collective labour action laws on blockholder effectiveness support the competitive perspective between stakeholders, the positive effect of labour laws mandating employee voice in firm decision-making is more in line with the cooperative view of corporate governance. This means we made reference to the literature on worker participation as well. The cooperative view of corporate governance could namely be explained by the fact that employee involvement in decision-making may foster the elimination of post-contractual information asymmetry (Freeman/Lazear 1995), increase investments in human capital (Furubotn 1988; Furubotn/Wiggins 1984) and enable the controlling owners to pursue valueenhancing quality management and innovative strategies (Kraft et al. 2011). In addition, with the globalisation of markets and the information revolution, which is a new phenomenon, Aoki (2010) proposes a RE mode of organisational architecture (reciprocal essentialities of management and workers cognitive assets). The growing importance of human cognitive assets, not limited only to those of management but also including those of the core workers, is the main ingredient of such a mode.

Two working hypotheses were made based on the literature review and description of the development of blockholdings and industrial relations in the Republic of Srpska. The first takes in the account the diversity of blockholdings based on 
different ownership arrangements and the divergent role of unions in organisations. Hence, corporate governance diversity should be an important feature of the corporate landscape in the Republic of Srpska. In view of the relationship between bargaining among corporate constituents and corporate governance, the working hypothesis is as follows:

Hypothesis 1: Blockholding behaviour differs in relation to the bargaining power dissimilarity found in corporate constituents.

However, this competitive approach among corporate constituents is often challenged by a more cooperative view, claiming that corporate constituents do not merely compete for the largest possible slice of the corporate pie, but also coordinate and cooperate strategically to increase the size of the pie which is to be distributed (Aoki 1984; Hall/Soskice 2001). In particular, organised workers in labour unions might positively affect blockholder effectiveness owing to decreased transaction costs and collective action problems, that burden dispersed employees to effectively pursue their interests in competition with other corporate constituents (Traxler 2003; Schnabel et al. 2006). The concentrated representation of labour interests can thus increase the likelihood of cooperation, producing benefits that dominate the costs to shareholders resulting from the empowering effects of unionisation. Likewise, value-enhancing cooperation between blockholders and labour may provide joint strategies that require firmspecific investments in human capital, worker empowerment and higher worker loyalty defining a firm's genetic material helping to achieve competitive advantage (Prašnikar et al. 2012; Van Essen et al. 2012). In addition, efficient bargaining between unions (workers) and the firm on employment and wages might better serve interests of both the firm and unions (workers). Such outcomes should be difficult to achieve if a monopoly union of workers pursues rent-seeking behaviour (maximisation of wages). This leads to the following working hypothesis presented in the form of two sub-hypotheses on the role of unions (workers) in blockholding relations in the Republic of Srpska:

Hypothesis 2a: Effectiveness of blockholdings is higher if unions (workers) are involved in strategic cooperation between employees and blockholders.

Hypothesis 2b: Effectiveness of blockholdings is lower if unions (workers) are seeking rent-motivated behaviour.

\section{Sample selection and questionnaire}

\subsection{Research design}

To test our working hypotheses we rely on questions posed to top managers in the firm. Managers were chosen as respondents because they possess comprehensive operational and strategic knowledge about the firm, as was required by the questionnaire. We were not in a position to obtain balance sheet data without 
the permission of companies. The primary data was acquired through a unique psychometric type of questionnaire associated with firm productivity, which was primarily developed and tested by Bloom and Van Reenen (2007). ${ }^{8}$

The survey was conducted in autumn 2011. We pilot tested the questionnaire on a few firms and selected 60 companies to compose a stratified sample on the basis of their size, industry and location which we believed were good representatives of companies with over 50 employees in the real sector of the economy. With the help of a research team from the University of Banja Luka, we appealed to the CEO of each company for collaboration, sent them the questionnaire, and received positive answers from 58 companies. We also collected data about individual characteristics of the surveyed firms, such as export orientation (share of revenues made abroad), ownership type (state or private, domestic or foreign, and dispersed or concentrated/blockholding), industry (service or manufacturing), and legal form (limited liability company or joint stock company). Firms were also asked to provide specific internal accounting information, from which we were able to calculate the added value per employee to use as a measure of their performance.

Manufacturing firms constitute $61.4 \%$ of the sample, $22.4 \%$ are state-owned firms, $15.5 \%$ are owned by foreigners, and $94.8 \%$ are block- owned. In 2011 , they generated $8.7 \%$ of total income and employed $5.4 \%$ of employees among all firms registered in the Republic of Srpska. In terms of the industries from which the surveyed firms were selected (mining, energy, manufacturing, construction, trade and other services) these blockholdings generated $20.9 \%$ of total income of these industries.

\subsection{Questionnaire structure}

The questionnaire consists of the following question sets: 1) decision-making, 2) adjusting employment, 3) wage setting, 4) the role of labour unions, 5) participation of workers in risk sharing, 6) participation of workers in decisionmaking, 7) internal training, and 8) on-job training. Since we are interested in the labour issues in blockholdings, each question set is related to a particular item from our literature review. The first is directly related to the role of workers in corporate governance, the next three deal with labour unions and bargaining, and the last four deal with the position of workers in building comparative advantages of firms. Thus, they are indirectly related to the role of workers in corporate governance as well. Each question set contains three consecutive statements to which managers responded positively ('yes') or negatively ('no'). Each

Psychometric questionnaires are most commonly used in psychology to conduct research in human psychological behaviour (i.g. Sixteen Personality Factor Questionnaire by Cattell 1946), frequently with the help of factor analysis in order to find latent behavioural traits (i.e. finding social value structures). For further reference please see Musek (1993). 
following statement in a question set represents a greater degree of complexity, building into a cascading structure. ${ }^{9}$

We start the first question set from the premise that a fundamental division between owners and managers is the division between the right to control (control rights), the right to bear risk and returns for taking risk (residual rights), and the right to decision-making (decision rights). The first two rights are in the domain of the owners of the firms whereas the last right regarding decisions on the use of existing resources belongs to managers. The choice about the separation of strategic function (given usually to top management) and day-to-day decisions (which are usually in the hands of middle and lower management) is in the hands of company owners (Wheelen/Hunger 2010), and they are responsible for addressing the agency problem which in turn leads to the (de)solution of consolidating owners' and managers' interests. Owners have the highest influence on (non-)cooperative behaviour of main corporate constituencies: owners, managers and workers (Aoki 1984; Van Essen et al. 2012).

In order to capture the employment adjustments (the second question set) of firms when they are confronted by external shocks, it is useful to start with a profit maximising model of a firm subject to capital and labour accumulation constraints. The derived static factor demand functions can be perceived as desired long-run equilibrium levels of labour and capital. In the absence of adjustment costs, firms constantly adapt employment to a desired level according to changes in market parameters (in particular, changes in output and wages) (Domadenik et al. 2008). Realistically, firm behaviour is dynamic rather than static and there are substantial adjustment costs. In constructing the questionnaire, this distinction was taken into consideration. Firms utilise different ways to restructure employment in the short term (using overtime, hiring part-time workers, employing through agencies, hiring students etc.), known as defensive labour re-structuring. In the long term they adjust desired employment by adjusting the number of full-time employees, noted as strategic restructuring of employment. In addition, we considered firms that based their competitive advantages on human capital to be building on the concept of core employees. The higher the share of core employees, the more is invested in a firm's human capital and the higher the firm's comparative advantage (Lepak et al. 2003; Aoki 2010; Zupan et al. 2010).

Deciding on wages (the third question set) is another important element in bargaining. In a mixed economy, such as the Republic of Srpska, which is marked by liberal relations toward employment and founding new companies on one side, and preserving institutions of collective bargaining in the labour market from the former Yugoslavia on the other side (path dependency), the size of

\footnotetext{
A combination of closed questions directs respondents to a systematic way of thinking about the actual situation in the organisation without being biased or thinking too broadly about it. See Bloom and Van Reenen (2010b) for an alternative view.
} 
wages (if they are higher than reservation wages ${ }^{10}$ ) is associated with collective bargaining processes at different levels. A negative answer to the first question in the question set relating to wages leads to the conclusion that workers are paid at the reservation wage. Furthermore, answering positively to the second question implies a positive deviation from the earnings assured by collective agreement. This either means higher bargaining power of unions, if they exist, or that the firm is building its compensation policies on the efficiency wage philosophy. When wages are among the highest in the country, either the first or second strategy is escalated.

To achieve greater bargaining power, employees organise themselves into labour unions (the fourth question set). Our first question was whether unions existed in the firm. We then tested the collaborative behaviour of unions. In the case of more competitive unions, the collaborative character of unions could diminish due to the competition between unions for membership, which is found especially in European states (Ferner/Hyman 1998). The final question relates to unions' concerns with the firm's success.

The fifth question set, entitled "Workers' Participation in Risk Sharing", first tests the willingness of employees to do 'something more' for the firm, which is a broad concept that can be understood in different ways. The key issue here is that workers are voluntarily prepared to spend their own time (outside working time) and energy in the benefit of the company, without any pressure or coercion from the employer. After testing workers' compliance, we focused on workers' long-term planning and loyalty to the firm by asking about their willingness to stay with the firm even if they had been offered better (paid) employment elsewhere. Lastly, we questioned workers on their propensity to financially participate in the firm and take financial risks.

In order to study the effect of workers' participation in the decision-making process on firm performance, we could categorise participation into levels or degrees. Clarke et al. (1972) distinguishes between participation concentrated on work tasks (work-centred participation) and participation concentrated on the distribution of power (power-centred participation). We have modelled our question set by Bernstein (1982), who distinguishes between four degrees of workers' control: 1) employee consultation represents the lowest degree of participation, where workers merely provide written or oral suggestions to management, which can choose to ignore or act on them, 2) employee co-influence involves discussions between workers and management, where workers have the right to be informed, discuss their interests, protest, and offer suggestions, but management still makes the final decision, 3) joint management, or co-determination, where both parties have the right to veto decisions and form joint decision committees, and 4) self-management, as the most advanced, enables full

10 The reservation wage is defined as the wage limit below which employees would be unwilling to work. 
participation of all members of the firm, with workers having total control over decision-making process. Since the Republic of Srpska normative framework does not support workers' participation, this questions set is comprised of questions which include the first three degrees of employee participation in the decision-making process. The first question, "Are workers informed about key decisions for the firm?" reflects employee consultation. The second question, "Is there an established open dialogue with the workers about key decisions for the firm?" expresses employee co-influence. The last question about workers being members of governing bodies includes joint management or codetermination.

Based on the notion that cooperative blockholdings also invest more in human capital, we chose to include this scope in our analysis. Investments in firmspecific human capital have been a long debatable issue in the economic profession. Following the resource-based view of firms, human capital was recognised as an important source of competitive advantage and a firm's ability to adapt in volatile environments (Barney 1991; Judge et al. 2009). Many researchers later identified firm-specific human and structural resources as the largest subcategory of businesses' intangible investment (Corrado et al. 2009, for the US and UK; Fukao et al. 2009, for Japan; Bloom/Van Reenen 2010a).

The seventh question set analyses internal training as a part of human capital practices in the firm. First we identified the company's intention to make collaborative efforts by asking about the provision of organised training based on identified needs of the company. Next, we determine the proportion of employees in training and establish the firm's dedication to measuring the effects of training. Firms that also measure training effectiveness with other methods, rather than solely by conducting a survey at the end of a training programme, are considered more dedicated.

By studying on-the-job training, we identified whether the company actually provides regular on-the-job training (e.g. apprenticeship, mentorship, job rotation etc.) and if it actively promotes spreading knowledge among its employees. If a firm considers on-the-job training an important factor in the promotion of key employees, it will foster successors for most of its key employees, allowing for quick and efficient replacements.

\section{Diversity and behaviour of blockholdings in the Republic of Srpska}

To identify the nature of corporate governance in the Republic of Srpska, we performed an agglomerative hierarchical cluster analysis in Stata SE 11. We adapted the simple Matching metric for calculating distances as one of the more suitable and most commonly applied metrics for clustering binary variables. To find the most suitable number of clusters, we chose as the most appropriate Ward's error sum of squares agglomeration method, which minimises variation 
within clusters (homogeneity) and maximises variation between clusters (heterogeneity) (Sharma 1996). ${ }^{11}$ We applied the second question in each question set as the clustering variable because they possess the most variability and are, therefore, the most suitable for clustering. ${ }^{12}$ We also used Pearson's Chi-square test to find differences between all three groups. The results are presented in Table 1 .

The cluster analysis identified two broad clusters that behave as WorkerEntrenched blockholdings and Worker-Liberal blockholdings based on the level and type of worker empowerment, with the latter further divided into two subgroups (sub-clusters) of predominantly manufacturing Core-Periphery firms and service RE firms to capture any further heterogeneity within the initial group. This confirms Hypothesis 1, which says that firm behaviour differs dependent on bargaining power dissimilarity. In the following subsections, we describe each type of blockholding in further detail.

\subsection{Cluster of worker-entrenched blockholdings}

In our discussion about the organisational architecture of firms in the Republic of Srpska, we particularly examined the group (first homogenous cluster) of 24 mostly unionised firms presented in the first two columns of the body of Table 1. Ninety-two percent of firms in this cluster have workers organised in unions, which institutionally empower (entrench) workers and represent their interests in the bargaining processes. Only one union organisation exists in $88 \%$ of firms. Compared to the second cluster, these proportions are high. In the first subgroup of the second cluster, unions only exist in approximately $11 \%$ of firms, while in the second subgroup unions are not present in any of the observed blockholdings.

11 To test the validity of results, we applied different distance measures and agglomerative techniques. By using Jaccard, Dice and Russel/Rao measures (Finch 2005), we got similar results as with simple Matching, but simple Matching produced the most significantly different clusters tested with Pearson's Chi-square. We also tried other agglomerative methods, such as single, average and complete linkage, but we encountered a problem with chaining, which is a common occurrence when clustering dichotomous variables. Performing clustering on subsamples provided reliability testing. This was inconclusive in some cases due to sample size limitation.

12 We also performed clustering by using all variables in the question sets and found similar results with less significant differences between clusters because of lost variability. The first questions have significantly more positive answers than negative answers, while vice versa is true for the third questions (a consequence of cascading). Therefore, the first and third questions have too low variability, making clustering problematic. 
Table 1: Blockholding types in the Republic of Srpska

\begin{tabular}{|c|c|c|c|c|c|c|c|c|}
\hline & \multirow{2}{*}{\multicolumn{2}{|c|}{$\begin{array}{c}\text { Worker- } \\
\text { entrenched } \\
\text { firms } \\
(\mathbf{n}=\mathbf{2 4})\end{array}$}} & \multicolumn{4}{|c|}{ Worker-liberal firms } & \multirow[b]{3}{*}{$\begin{array}{l}\text { Chi- } \\
\text { square }\end{array}$} & \multirow[b]{3}{*}{ Sign. } \\
\hline & & & \multicolumn{2}{|c|}{$\begin{array}{c}\text { Core- } \\
\text { periphery } \\
\text { mode } \\
(\mathrm{n}=18)\end{array}$} & \multicolumn{2}{|c|}{$\begin{array}{c}\text { RE mode } \\
(\mathrm{n}=16)\end{array}$} & & \\
\hline & & & $\begin{array}{c}\% \\
\text { yes } \\
\end{array}$ & & $\begin{array}{c}\% \\
\text { yes } \\
\end{array}$ & & & \\
\hline \multirow{3}{*}{$\begin{array}{l}\text { 1. THE DECISION-MAKING } \\
\text { Operation/strategic management separated } \\
\text { Managers and owners act unanimously } \\
\text { Owners, managers and workers coordinate } \\
\text { decisions }\end{array}$} & 70.8 & 46.4 & 72.2 & 46.1 & 100 & & 5.776 & 0.056 \\
\hline & 70.8 & 46.4 & 55.6 & 51.1 & 100 & 0.0 & 8.960 & 0.011 \\
\hline & 58.3 & 50.4 & 38.9 & 50.2 & 68.8 & 47.9 & 3.219 & 0.200 \\
\hline \multirow{3}{*}{$\begin{array}{l}\text { 2. DECISIONS ON EMPLOYMENT } \\
\text { Short-term adjustments to shocks are appropriate } \\
\text { Achieving desired level of employment } \\
\text { Existence of core group of employees as a compara- } \\
\text { tive advantage }\end{array}$} & & & & & & & & \\
\hline & $\begin{array}{l}83.3 \\
54.2\end{array}$ & $\begin{array}{l}38.1 \\
50.9\end{array}$ & $\begin{array}{l}94.4 \\
83.3\end{array}$ & $\begin{array}{l}23.6 \\
38.3\end{array}$ & $\begin{array}{l}87.5 \\
62.5\end{array}$ & $\begin{array}{l}34.2 \\
50.0\end{array}$ & $\begin{array}{l}1.200 \\
3.962\end{array}$ & $\begin{array}{l}0.549 \\
0.138\end{array}$ \\
\hline & 37.5 & 49.5 & 55.6 & 51.1 & 56.3 & 51.2 & 1.906 & 0.386 \\
\hline \multicolumn{3}{|l|}{ 3. DECISIONS ON WAGES } & 22.2 & 42.8 & 100 & 0.0 & 24.310 & 0.000 \\
\hline Wages higher than collective ag & 41.7 & 50.4 & 11.1 & 32.3 & 68.8 & 47.9 & 11.829 & 0.003 \\
\hline Wages among the highest in & 37.5 & 49.5 & 5.6 & 23.6 & 56.3 & 51.2 & 10.300 & 0.006 \\
\hline \multicolumn{3}{|l|}{ 4. THE UNION ROLE } & & & & & & \\
\hline Workers organised in unions & 91.7 & 28.2 & 11.1 & 32.3 & 0.0 & 0.0 & 43.113 & 0.000 \\
\hline One union organisation exists & 87.5 & 33.8 & 11.1 & 32.3 & 0.0 & 0.0 & 39.601 & 0.000 \\
\hline Unions concerned with a firm's success & 37.5 & 49.5 & 5.6 & 23.6 & $\mathbf{0 . 0}$ & 0.0 & 11.959 & $\mathbf{0 . 0 0 3}$ \\
\hline \multicolumn{3}{|l|}{$\begin{array}{l}\text { 5. WORKERS INCLINATION TOWARDS } \\
\text { RISK }\end{array}$} & & & & & & \\
\hline Workers are prepared to do "more" for the firm & 83.3 & 38.1 & 72.2 & 46.1 & 100 & 0.0 & 5.027 & 0.081 \\
\hline Workers would stay with the firm in $b$ & 62.5 & 49.5 & 33.3 & 48.5 & 75.0 & 44.7 & 6.521 & 0.038 \\
\hline Workers are willing to & 37.5 & 49.5 & 11.1 & 32.3 & 43.8 & 51.2 & 5.016 & 0.081 \\
\hline \multicolumn{3}{|l|}{ 6. WORKERS PARTICIPATION } & & & & & & \\
\hline Workers are informed about key decisio & 66.7 & 48.2 & $\mathbf{5 0 . 0}$ & 51.4 & 100 & 0.0 & 10.540 & 0.005 \\
\hline Workers have an open dialogue & 62.5 & 49.5 & 44.4 & 51.1 & 100 & 0.0 & 12.286 & 0.002 \\
\hline Workers are members of gover & 45.8 & 50.9 & 5.6 & 23.6 & 43.8 & 51.2 & 8.787 & 0.012 \\
\hline \multicolumn{3}{|l|}{ 7. INTERNAL TRAINING } & & & & & & \\
\hline Frintone of ornind foum & 100 & & 66.7 & 48.5 & 81.3 & 40.3 & 8.894 & 0.012 \\
\hline More than $50 \%$ of workers parti & 41.7 & 50.4 & 33.3 & 48.5 & 50.0 & 51.6 & 0.971 & 0.615 \\
\hline Other methods of evaluation th & 29.2 & 46.4 & 5.6 & 23.6 & 18.8 & 40.3 & 3.732 & 0.155 \\
\hline \multirow{3}{*}{$\begin{array}{l}\text { 8. ON-THE-JOB TRAINING } \\
\text { Existence of organised forms in the firm } \\
\text { Systematic knowledge transfer among employees } \\
\text { exists } \\
\text { Successors for most of key employees exists }\end{array}$} & 91.7 & 28.2 & 55.6 & 51.1 & 100 & 0.0 & 14.003 & 0.001 \\
\hline & 87.5 & 33 & 55.6 & 51.1 & 100 & 0.0 & 12.000 & 0.002 \\
\hline & 79.2 & 41.5 & 44.4 & 51.1 & 62.5 & 50.0 & 5.385 & 0.068 \\
\hline \multirow[t]{5}{*}{ ADDITIONAL INFORMATION } & & & & & & & & \\
\hline & 45.8 & 50.9 & 33.3 & 48.5 & 75.0 & 44.7 & 6.167 & 0.046 \\
\hline & $26.1^{\mathrm{a}}$ & 44.9 & 22.2 & 42.8 & 75.0 & 44.7 & 12.501 & 0.002 \\
\hline & 37.5 & 49.5 & 55.6 & 51.1 & 87.5 & 34.2 & 9.805 & 0.007 \\
\hline & 70.8 & 46.4 & 16.7 & 38.3 & 12.5 & 34.2 & 18.887 & 0.000 \\
\hline More than $0 \%$ of export & 54.2 & 50.9 & 55.6 & 51.1 & 50.0 & 51.6 & 0.114 & 0.945 \\
\hline More than $25 \%$ of export & 41.7 & 50.4 & 38.9 & 50.2 & 18.8 & 40.3 & 2.456 & 0.293 \\
\hline More than $50 \%$ of export & 20.8 & 41.5 & 22.2 & 42.8 & 12.5 & 34.2 & 0.614 & 0.736 \\
\hline Foreign ownership & 16.7 & 38.1 & 11.1 & 32.3 & 18.8 & 40.3 & 0.418 & 0.811 \\
\hline State ownership & 37.5 & 49.5 & 16.7 & 38.3 & 6.3 & 25.0 & 5.887 & 0.053 \\
\hline Block ownership: more than & 91.7 & 28.2 & 100 & 0.0 & 93.8 & 25.0 & 1.509 & 0.470 \\
\hline
\end{tabular}


On average, the blockholdings in this cluster are larger, coming mainly from the manufacturing sector. The prevailing legal status is the joint stock company (although $38 \%$ of firms are limited liability companies). The firms do not deviate positively or negatively in productivity ${ }^{13}$ since $46 \%$ of companies in the cluster show higher productivity than the median productive firm in the sample. Moreover, $38 \%$ of firms in this cluster are state-owned companies. The proportion of state-owned companies is much higher than in the second cluster. Almost onefifth of firms in the cluster are foreign-owned companies; others are voucherprivatised and de-novo companies.

Data in Table 1 shows that operations and strategic management decisions in these firms are separated in approximately $71 \%$ of firms. In the same share of firms, managers and owners act unanimously and there is very high coordination of basic strategic decisions between owners, managers and workers (in 58\% of firms). Eighty-three percent of firms claim that short-term adjustments to shocks are appropriate and use flexible employment arrangements to achieve these adjustments. The most widely applied forms of flexible employment arrangements are part-time employments, hiring students and using overtime work. $^{14}$

This group of firms achieved the lowest level of desired employment and has the lowest assertion of the core group of employees concept among all three clusters of firms. Wages are higher than alternative wages in $75 \%$ of all companies, higher than those set by collective agreements in $42 \%$ of firms and among the highest in the country in $38 \%$ of cases. As mentioned earlier, there is one union organisation operating in most of the firms and 38\% of companies claim that unions are concerned with the firm's success. With regard to loyalty, more than $80 \%$ perceive their employees as willing to do something more for the firm. About $60 \%$ of companies believe that employee loyalty level is high and that employees would remain with the firm even if they were offered a slightly better employment opportunity (e.g. better paid job). In almost $40 \%$ of all cases, workers would even be willing to make financial investments in a firm. Two-thirds of firms claim to use a participative style of leadership with employees having the right to voice their opinions, which are taken into account when making managerial decisions. One aspect of participative leadership is the presence of workers in government bodies, which exists in almost one-half of the compa-

13 Productivity was measured by added value per employee, which was used to make a dummy variable. Firms with added value per employee less than or equal to the sample median were given the value 0 , and firms with added value per employee more than the sample median were given the value 1 .

14 Based on managers' ranking of adjustment methods to short-term demand fluctuations, hiring part-time workers is by far the most often applied method (on a scale from $1=$ "most used" to $5=$ "least used," Friedman rank is 2.42). It is followed by hiring students (3.84), using overtime work (4.00), employing through agencies (4.06), using reduced working time (4.62) and using work on hold (4.74). 
nies. With regard to human capital investment, all companies reported training organised in line with company requirements. Moreover, the training participation levels exceed one-half of employees in $40 \%$ of the companies. Only onethird of firms show the presence of other methods of evaluation rather than a survey. More than $90 \%$ also reported having formal programmes of on-the-job training, and only a few less claim to support a formal transfer of knowledge, mostly through mentorships, instructions and teamwork. Seventy-nine percent of firms believe to have competent successors for the key positions in the company, which is achieved through the internal transfer of knowledge.

However, this highly positive image of the collaborative effects between unions and blockholders, which would confirm Hypothesis $2 \mathrm{a}$, becomes less convincing if we make an internal comparison of firms in this cluster of mostly unionised companies. Although the total number of firms is low, a more in-depth analysis shows that firms differentiate to a certain degree. Let us consider, for example, state-owned firms (nine) and foreign-owned firms (four). Wages in stateowned firms are higher than those set by collective agreements and are among the highest in the country in almost $80 \%$ of cases. All of these firms claim that workers are prepared to do 'something more' for the firm and would stay with the firm also in harsh economic times. In two-thirds of state-owned firms, workers are willing to make financial investments in the firm. However, only three state-owned firms claim to have achieved a desired level of employment. On the contrary, all foreign-owned firms have a desired level of employment. Wages are higher than those set by the collective agreement only in one case. Workers in foreign-owned firms are also more prone to leaving the firm in bad times and are not willing to make financial investments in the firm. On the other hand, foreign firms involve more than one-half of workers in internal training relatively more often than state firms. In relative terms, they also outnumber the state-owned firms in using other methods of evaluation rather than mere surveys. ${ }^{15}$

On the basis of our data, it seems that state-owned firms might resemble the behavioural characteristics of Yugoslav firms (companies managed by workers, managers and the government), where unions played an important role in defending workers' employment and wages in centralised collective bargaining processes (Prašnikar/Svejnar 1991). Good examples of such governance arrangement are the prevailing state-owned companies in the energy sector. The collective agreement in the energy sector includes a list of different compensations, including a tenure premium that puts younger workers in a disadvantaged position compared to older workers. The agreement also includes collective health insurance, new year packages for children, payment for every newborn child, payment for international labour day, payment for different sorts of bene-

15 A more detailed analysis is available upon request. 
fits for retirees and families of the deceased workers etc., which is not included in most other collective agreements.

Due to possibility of rent-seeking behaviour emerging in the state-owned firms, a possible explanation of the highest self evaluation of internal training and onthe-job training, among all firms in the sample, might be that some of these firms do not differentiate between investments in firm-specific human capital that is expected to be value-enhancing from investments in firm-specific human capital for which this is not the case (Micco/Pages 2004; Van Essen et al. 2012). These results suggest that Hypothesis $2 b$ could be confirmed in the case of state-owned unionised firms.

\subsection{Cluster of worker-liberal blockholdings}

The second studied broad cluster consists of 34 Worker-Liberal (mainly nonunionised) blockholdings with a union organisation present only in two cases. These firms are, on average, smaller than those in the first cluster. The cluster is further divided into two subgroups, i.e. in 18 Core-Periphery firms mostly from the manufacturing sector (almost $80 \%$ of firms in the first subgroup fall into this category) and $16 \mathrm{RE}$ mode firms mainly from the service sector (three-quarters of firms in the second subgroup fall into service industries). Columns 3 to 6 in the body of Table 1 show different behavioural patterns of the two subgroups, which are further described in the following two subsections.

\subsubsection{Worker-liberal manufacturing-oriented blockholdings}

These manufacturing blockholdings are smaller compared to the first cluster (see columns 3 and 4 in the body of Table 1). Limited liability companies prevail in terms of legal status $(56 \%)$ and there are fewer firms having state ownership $(17 \%)$. A check of the ownership structures shows that a number of blockholdings in this group belonging to privatised, formerly socially-owned firms. They are among the least productive (only one-third of firms in the group show higher productivity than the median firm).

As it is evident from the results in Table 1, the decisions in this subgroup are made with the lowest level of consensus between the owners and managers. Decisions are coordinated among owners, managers and workers in less than twofifths of firms, and the decision-making power is highly concentrated in the hands of managers (or owners). Short-term labour adjustments to shocks were executed in $95 \%$ of cases, ${ }^{16}$ and firms adjusted employment to a desired level in more than $80 \%$ of cases. The concept of core employment is observed in $55 \%$ of firms. In most cases the wages are close to the alternative wage. The study re-

16 Based on managers' ranking of adjustment methods to short-term demand fluctuations, hiring part-time workers is most commonly applied (Friedman rank: 2.53). It is followed by using overtime work (3.61), using reduced working time (3.78), employing through agencies (4.36), using work on hold (4.56) and hiring students (4.58). 
vealed that these workers are paid the lowest wage and also have the lowest risk propensity. They are willing to stay with a firm in only one-third of cases at times of economic distress (crisis). Since the economic situation of many firms is currently aggravated, most workers would probably leave the firm if an opportunity arose. The share of firms in which workers participate, as well as the share of firms having investment in human capital, is low compared to other groups of firms. In a series of these firms they do not provide employees with even basic information about company operations. The relationship with workers is mostly transactional.

Core-Periphery employment relationships are more evident in this cluster than in the cluster of Worker-Entrenched firms. This phenomenon is similar to the description of Deakin and Reberiouxa (2009), where many companies in France are reducing the proportion of core employees in favour of agency labour and subcontracting peripheral jobs owing to pressure from financial markets. This type of firm is often found in regions of the former Yugoslavia due to one further reason: a non-transparent lengthy privatisation of former socialist firms which is, in some cases, still not completed and is characterised by frequently changing privatisation methods. ${ }^{17}$ Both tendencies are also evident from our data. Firms studied in this segment operate on the verge of economic efficiency as they are more extensively involved in foreign trade, where they are faced with a higher level of competition (see additional information in Table 1). Moreover, non-transparency and corruption of fast ownership concentration in the hands of new owners are often cited as the main reasons for dissatisfaction in certain firms where managers (owners) exercised high controlling power. ${ }^{18}$ Consequent-ly, these firms are, in most cases, domestically owned.

\subsubsection{Worker-liberal service-oriented blockholdings}

This subgroup comprises mainly of limited liability companies. Their productivity is higher than in the median firm in $77 \%$ of cases, which makes this group of firms the most productive of all three clusters. What would be the driver of above average efficiency of this subgroup of firms? Our data could certainly point to one fact. Namely, this group of firms is characterised by cooperative behaviour between the main stakeholders (managers, workers and owners), which might be value enhancing. This is already evident from the answers received to the first set of questions. The results about the level of cooperation in decision-making under the $5^{\text {th }}$ and $6^{\text {th }}$ column of Table 1 body show a high level of consensus between owners and managers, and coordination of decisions with workers as well. Firms adjust well to short-term employment, economic

\footnotetext{
17 In a study of Montenegrin firm behaviour in the period from 1998 to 2009, Koman et al. (2013) found that too many Montenegrin firms have been lost in the privatisation process due to badly designed and nontransparent rules. Stripping assets was a more lucrative strategy than building value.

18 See for example World Bank (2000).
} 
shocks $^{19}$ and to a desired level of employment. Firms also highly address the concept of a core group of employees. Workers have higher wages than those set by collective agreements in almost $70 \%$ of firms. It was claimed by $57 \%$ of firms that they are among the highest in the country.

Workers' participation in decision-making is observed in almost all firms. Workers are well informed, have an open dialogue with managers, are members of governing bodies in $45 \%$ of firms, and their risk propensity is high. They are willing to make financial investments in the firm in $43 \%$ of cases. Investments in human capital, in the form of investments in internal training as well as onthe-job training, are present in the majority of firms. Yet, workers in these firms are not organised in unions. Collaboration with managers (owners) is voluntary and developed as a result of mutual recognition that management's capabilities and workers' capabilities are necessary for value-enhancing activities. Their cooperation is an important factor of company success.

This group of firms resembles the RE model developed by Aoki (2010) in which the cognitive assets of management (MCA) and those of workers (WCA) are reciprocally essential. Without joint cooperation, neither of them can increase marginal product simply by substituting the use-control of non-human, physical assets (PHA) to the other. The results also support Hypothesis 2a. Such internal environment evolved especially in the service sector (three-quarters), which presented one of the major shortcomings of the former Yugoslavia along with the absence of small and medium-sized enterprises (Petrin/Vahčič 1990), and was, thus, able to attract a young, educated labour force.

\section{Conclusion, limitations and future directions}

The Republic of Srpska is one of the entities constituting Bosnia and Herzegovina and a representative case of a transitional economy where we were able to study corporate governance and productivity differentiation through the development of labour market institutions. There is almost no information on this issue available from countries of the former Yugoslavia, where peculiar labour relations played an important role in the past. The Republic of Srpska preserved Yugoslav labour institutions long after the disintegration of Yugoslavia occurred in 1991. However, the situation has been strongly influenced by economic reforms on account of privatisation, liberalisation, and globalisation in the past decade. One of the purposes of privatisation was to reform corporate governance and increase firm efficiency. The shareholder-oriented model was perceived as becoming the prevailing mode of a firm's corporate governance. However, our results indicate that voucher-privatised firms in the Republic of Srpska are a temporary phenomenon. As mass privatisation was introduced along with the

19 Managers ranking of adjustment methods to short-term fluctuations in demand gave priority to hiring parttime workers (Friedman rank: 2.66). It is followed by employing people through agencies (3.63), using overtime work (3.63), hiring students (3.91), using reduced working time (4.59) and work on hold (4.56). 
launch of liberal reforms, a convergence to concentrated ownership and diversity of blockholdings is a prevalent tendency under these circumstances.

By studying blockholdings in the Republic of Srpska, we identified various types of corporate behaviour and organisational architecture transformations in the framework of different labour institutional arrangements. Significant differences in blockholdings' behaviour, based on the level and type of (institutional) empowerment of workers, can be observed. Our analysis identified two broad clusters that behave as Worker-Entrenched blockholdings and Worker-Liberal blockholdings, with the latter further divided into two subgroups of predominantly manufacturing Core-Periphery mode firms and service ReciprocalEssentials (RE) mode firms. In Worker-Entrenched blockholdings most workers are members of (mainly one) labour unions, and achieved fairly good results in terms of collaborative efforts of blockholders and unions. But, some unions (particularly in state-owned firms) might evolve rent-seeking behaviour.

Most workers in the cluster of Worker-Liberal blockholdings are not associated with unions. The owners and/or managers are the dominant decision makers in the first subgroup of profit-maximising, Core-Periphery firms, which are the least productive. The Core-Periphery model is likely to be the outcome in many cases of privatised firms. The second subgroup of blockholdings with Reciprocal-Essentials (RE) mode of organisational architecture has developed under the influence of technological changes. It represents an important segment of business that emphasises reciprocity of management and core workers' cognitive assets, and is the most productive of all groups.

Different labour relations in firms and various types of corporate governance resulted in blockholding diversity that might promote the selection of corporate governance modes in favour of those that utilise new technologies better and increasingly on the global scene. The RE model is a very good example of such type of firms. Diversity also makes an economic system more adaptable to environmental change, as well as more robust to economic shocks.

The case of the Republic of Srpska clearly shows that a design toward a unified group of firms was a difficult endeavour and that it failed for different reasons. ${ }^{20}$ Thes endeavour also brought along some lessons that are important in a broader context. Collaborative effort on the side of blockholders and unions (workers) could be value enhancing and might increase the company efficiency. However, a monopoly-oriented union could present an obstacle for further development of this collaborative approach. This means that institutional similarities to the Yugoslav system, cooperative behaviour of constituents on the one side and high impact of the state and politically influenced unions on outcomes of central bar-

20 See Samuelson (1954; 1955), Grove and Ledyard (1977) and Hurwicz (1994) on the problems of evolution and design in economic processes and development. 
gaining on the other side, are still present and they affect the way companies and organisation behave.

Groups of firms in this study were obtained through the analysis of a unique dataset. The data was gathered through a psychometric questionnaire asking managers about different characteristics of decision-making in the firm. We applied a technique of cascading closed questions. In some cases, open questions might have been better, but enterprises in the Republic of Srpska do not have experience with (such) research, so managers were suspicious about their rationale and, therefore, reluctant to cooperate.

The limited sample size is a limitation of this study. However, we are satisfied with the number of responses considering the circumstances. This research gives hope that even more companies will be prepared to cooperate in the future and make research in the respective region.

\section{References}

Aguilera, R.V./Jackson, G. (2003): The cross-national diversity of corporate governance: Dimensions and determinants, in: Academy of Management Review, 28, 3, 447-465.

Aguilera, R.V./Filatotchev, I./Gospel, H./Jackson, G. (2008): An organizational approach to comparative corporate governance: Costs, contingencies, and complementarities, in: Organization Science, 19, 3, 475-492.

Aoki, M. (1984): The co-operative game theory of the firm. Oxford: Clarendon Press.

Aoki, M. (2010): Corporations in Evolving Diversity. Oxford: Oxford University Press.

Aoki, M./Jackson, G. (2008): Understanding an emergent diversity of corporate governance and organizational architecture: An essentiality-based analysis, in: Industrial and Corporate Change, 17, 1, 1-27.

Barney, J. (1991): Firm Resources and Sustained Competitive Advantage, in: Journal of Management, 17, 1, 99-120.

Bernstein, P. (1982): Necessary Elements for Effective Worker Participation in DecisionMaking. Workplace Democracy and Social Change. Boston: Porter Sargent Publishers.

Black, B.S. (1990): Shareholder passivity re-examined, in: Michigan Law Review, 89, 3, 520608.

Bloom, N./Van Reenen, J. (2007): Measuring and Explaining Management Practices Across Firms and Countries, in: Quarterly Journal of Economics, 72, 4, 1351-1367.

Bloom, N./Van Reenen, J. (2010a): Why do management practices differ across firms and countries, in: Journal of Economic Perspective, 24, 1, 203-224.

Bloom, N./Van Reenen, J. (2010b): New Approaches in Surveying Organizations, in: American Economic Review, 100, 2, 105-109. 
Bratton, W./McCahery, A. (2002): Comparative Corporate Governance and Barriers to Global Cross Reference, in: McCahery, J.A./Moerland, P./Raaijmakers, T./Renneboog, L. (eds.): Corporate Governance Regimes. Convergence and Diversity. Oxford University Press, 22-56.

Cattell, R.B. (1946): The description and measurement of personality. New York: World Book.

Clarke, R.O./Roberts, B.C./Fatchet, D.J. (1972): Workers' Participation in Management in Britain. London: Heinemann Education.

Corrado, C./Hulten, C./Sichel, D. (2009): Intangible Capital and U.S. Economic Growth, in: Review of Income and Wealth, 55, 3, 661-685.

Cronqvist, H./Fahlenbrach, R.D. (2009): Large shareholders and corporate policies, in: Review of Financial Studies, 22, 10, 3941-3976.

Damijan, J./Gregorič, A./Prašnikar, J. (2004): Ownership concentration and firm performance in Slovenia, in: LICOS Discussion Papers. KU Leuven.

Deakin, S./Reberioux, A. (2009): Corporate governance, labour relations and human resource management in Britain and France: Convergence or divergence?, in Touffut, J.P. (ed.): Does Company Ownership Matter? Cheltenham: Edward Elgar Publishing.

Dedic, V. (2013): Annual Review 2012 on Labour Relations and Social Dialogue in South East Europe: Bosnia and Herzegovina. Friedrich-Ebert-Stiftung.

Demsetz, H./Lehn, K. (1985): The Structure of Corporate Ownership: Causes and Consequences, in: Journal of Political Economy, 93, 6, 1155-1177.

Domadenik, P./Prašnikar, J./Svejnar, J. (2008): Restructuring of Firms in Transition: Ownership, Institutions and Openness to Trade, in: Journal of International Business Studies, $39,4,725-746$.

Dyck, A./Zingales, L. (2004): Private benefits of control: An international comparison, in: The Journal of Finance, 59, 2, 537-600.

Earle, J.S./Kucsera, C./Telegdy, A. (2005): Ownership Concentration and Corporate Performance on the Budapest Stock Exchange: do too many cooks spoil the goulash?, in: Corporate Governance, 13, 2, 254-264.

EBRD. (2010): Transition Report, European Bank for Reconstruction and Development. URL: http://www.ebrd.com/pages/research/publications/flagships/transition.shtml.

EBRD. (2011). Transition Report, European Bank for Reconstruction and Development. URL: http:/www.ebrd.com/pages/research/publications/flagships/transition.shtml.

Edmans, A. (2009): Blockholder Trading, Market Efficiency, and Managerial Myopia, in: The Journal of Finance, 64, 6, 2481-2513.

Ehrenberg, R./Smith, R. (2011): Modern Labour Economics. New Jersey: Prentice Hall.

Estrin, S./Laidler, D./Dietrich, M. (2008): Microeconomics. Harlow: FT Prentice Hall.

Fama, E. (1980): Agency problems and the theory of the firm, in: Journal of Political Economy, 88, 2, 288-307.

Fama, E./Jensen, M. C. (1985): Organizational forms and investment decisions, in: Journal of Financial Economics, 14, 1, 101-119. 
Ferner, A./Hyman. R. (1998): Changing industrial relations in Europe. Hoboken: WileyBlackwell.

Finch, H. (2005): Comparison of Distance Measures in Cluster Analysis with Dichotomous Data, in: Journal of Data Science, 3, 1, 85-100.

Finkelstein, S./Boyd, B. (1998): How Much Does the CEO Matter? The Role of Managerial Discretion in the Setting of CEO Compensation, in: Academy of Management Journal, 41, 2, 179-199.

Freeman, R./Lazear, E. (1995): An Economic Analysis of Works Councils, NBER Chapters, in: Works Councils: Consultation, Representation, and Cooperation in Industrial Relations. National Bureau of Economic Research, Inc., 27-52.

Fukao, K./Miyagawa, T./Mukai, K./Shinoda, Y./Tonogi, K. (2009): Intangible Investment in Japan: Measurement and Contribution to Economic Growth, in: Review of Income and Wealth, 55, 3, 717-736.

Furubotn, E.G. (1988): Codetermination and the modern theory of the firm: A property rights analysis, in: Journal of Business, 61, 165-181.

Furubotn, E.G./Wiggins, S.N. (1984): Plant Closing, Worker Reallocation Costs and Efficiency Gains to Labor Representation on Boards of Directors, in: Journal of Institutional and Theoretical Economics/Zeitschrift für die gesamte Staatswissenschaft, 140, 176-192.

Grove, T./Ledyard, J. (1977): Optimal Allocation of Public Goods: a Solution to the Free Rider Problem, in: Econometrica, 45, 4, 783-811.

Hall, P.A./Soskice, D.W. (2001): Varieties of capitalism: The institutional foundations of comparative advantage. Oxford: Oxford University Press.

Hansmann, H./Kraakman, R. (2001): The end of history for corporate law, in: Georgetown Law Journal, 89, 2, 439-468.

Henrekson, M./Jakobsson, U. (2012): The Swedish Corporate Control Model: Convergence, Persistence or Decline?, in: Corporate Governance: An International Review, 20, 2, 212-227.

Hoff, K./Stiglitz, J.E. (2004): After the Big Bang? Obstacles to the Emergence of the Rule of Law in Post-Communist Societies, in: American Economic Review, 94, 3, 753-763.

Holderness, C./Sheehan, D. (1988): The role of majority shareholders in publicly held corporations, in: Journal of Financial Economics, 20, 317-346.

Holderness, C/Krozsner, R/Sheehan (1999): Were the good old days that good? Changes in managerial stock ownership since the great depression, in: The Journal of Finance, 54, 435-469.

Holderness, C.G. (2003): A survey of blockholders and corporate control, in: Federal Reserve Bank of New York Policy Review, 9, 1, 51-64.

Hopner, M. (2005): What connects industrial relations and corporate governance? Explaining institutional complementarity, in: Socio-Economic Review, 3, 2, 331-358.

Hoskisson, R.E./Hitt, M.A./Johnson, R.A./Grossman, W. (2002): Conflicting voices: The Effects of Institutional Ownership Heterogeneity and Internal Governance on Corporate Innovation Strategies, in: Academy of Management Journal, 45, 697-716. 
Hurwicz, L. (1994): Economic Design, Adjustment Processes, Mechanisms, and Institutions, in: Economic Design, 1, 1, 1-14.

IMF. (2005). Bosnia and Herzegovina: Selected Issues- The Corporate Sector. URL: http:// www.imf.org/external/pubs/ft/scr/2005/cr05198.pdf.

Jensen, M.C./Meckling, W.H. (1976): Theory of the firm: Managerial behavior, agency costs and ownership structure, in: Journal of Financial Economics, 3, 4, 305-360.

Johnson, S./La Porta, R./Lopez-de-Silanes, F./Shleifer, A. (2000): Tunneling, in: American Economic Review, 90, 2, 22-27.

Judge, W./Naoumova, I./Douglas, T. (2009): Organizational capacity for change and firm performance in a transition economy, in: International Journal of Human Resource Management, 20, 8, 1737-1752.

Koman, M./Lakicević, M./Prašnikar, J./Svejnar, J. (2013): Asset stripping. Application of Hoff-Stiglitz model to Montenegro mass voucher privatization.

Kraft, K./ Stank, J./ Dewenter, R. (2011): Co-determination and innovation, in: Cambridge Journal of Economics, 35, 1, 145-172.

La Porta, R./Lopez-De-Silanes, F./Shleifer, A. (2008): The economic consequences of legal origins, in: Journal of Economic Literature, 46, 2, 285-332.

Lepak, D.P./Takeuchi, R./Snell, S.A. (2003): Employment Flexibility and Firm Performance: Examining the Interaction Effects of Employment Mode, Environmental Dynamism, and Technological Intensity, in: Journal of Management, 29, 5, 681-703.

Maug, E. (1998): Large shareholders as monitors: Is there a trade-off between liquidity and control?, in: Journal of Finance, 53, 1, 65-98.

Micco, A./Pages, C. (2004): Employment protection and gross job flows: A differences-indifferences approach. Washington: World Bank.

Mikerević, D. (2012): Analysis of Yield, Property and Financial Position of Republic of Srpska Economy in 2011, in: Mikerević, D. (ed.): Overcoming the crisis with changes in strategies, policies and models of corporate governance. Banja Luka: Finrar.

Musek, J. (1993): Osebnost in vrednote. Ljubljana: Educy.

OHR (ed.) (2004): Izvještaj OHR-a i specijalnog predstavnika EU za BiH Evropskom parlamentu: juni - decembar 2004. URL: http://www.ohr.int/other-doc/hr-reports/default .asp?content_id $=36801$.

Petrin, T./Vahčič, A. (1990): Restructuring of Yugoslav economy through development of entrepreneurship and the role of the financial system, in: Slovene Studies Journal, 12, $1,67-74$.

Prašnikar, J./Redek, T./Drenkovska, M./Voje D. (2012): Innovation in Slovenia as an indicator of companies' generic material potential, in: Prašnikar, J. (ed.): Comparing companies' success in dealing with external shock : The case of Western Balkans, Mediterranean countries and Core European countries. Ljubljana: Časnik Finance.

Prašnikar, J./Svejnar, J. (1991): Workers participation in management vs. social ownership and government policies: Yugoslav lessons for transforming socialist economies, in: Comparative economic studies, 4, 27-45. 
Samuelson, P. (1954): The Pure Theory of Public Expenditure, in: Review of Economics and Statistics, 36, 4, 387-389.

Samuelson, P. (1955): Diagrammatic Exposition of a Theory of Public Expenditure, in: Review of Economics and Statistics, 37, 4, 360-366.

Sanchez-Ballesta, J.P./Garcia-Meca, E. (2007): A Meta-Analytic Vision of the Effect of Ownership Structure on Firm Performance, in: Corporate Governance: An International Review, 15, 5, 879-892.

Schnabel, C./Zagelmeyer, S./Kohaut, S. (2006): Collective bargaining structure and its determinants: An empirical analysis with British and German establishment data, in: European Journal of Industrial Relations, 12, 2, 165-188.

Sharma, S. (1996): Applied Multivariate Techniques. New York: John Wiley \& Sons.

Shleifer, A./Vishny, R.W. (1986): Large Shareholders and Corporate Control, in: Journal of Political Economy, 94, 3, 461-488.

Shleifer, A./Vishny, R.W. (1997): A Survey of Corporate Governance, in: The Journal of Finance, 52, 2, 737-783.

Službeni Glasnik RS 55/07 (2007): Zakon o radu. URL: http://www.unijauprs.org/zakoni /ZOR.pdf.

Stanković, G. (2012): Annual Review 2011 on Labour Relations and Social Dialogue in South East Europe: Bosnia and Herzegovina. Friedrich-Erbert-Stiftung.

Svejnar, J. (1986): Bargaining Power, Fear of Disagreement, and Wage Settlements: Theory and Evidence from U.S. Industry, in: Econometrica, 54, 5, 1055-1078.

Thomsen, S./Pedersen, T. (2000): Ownership structure and economic performance in the largest European companies, in: Strategic Management Journal, 21, 6, 689-705.

Tosi, H.L./Katz, J.P./Gomez-Mejia, L.R. (1997): Disaggregating the Agency Contract: The Effects of Monitoring, Incentive Alignment, and Term in Office on Agent Decision Making, in: Academy of Management Journal, 40, 3, 584-602.

Traxler, F. (2003): Bargaining (de)centralization, macroeconomic performance and control over the employment relationship, in: British Journal of Industrial Relations, 41, 1, 127.

Tribo, J.A./Berrone, P./Surroca, J. (2007): Do the Type and Number of Blockholders Influence R\&D Investments? New evidence from Spain, in: Corporate Governance: An International Review, 15, 5, 828-842.

Van Essen, M./Van Oosterhout, J./Heugens, P. (2012): Competition and cooperation in corporate governance: the effects of labor institutions on blockholder effectiveness in 23 European countries, in: Organization Science, 24, 2, 530-551.

Wheelen, T.L./Hunger, D.L. (2010): Strategic management and business policy. New Jersey: Prentice Hall.

World Bank (ed.) (2000): Bosnia and Herzegovina Diagnostic Surveys of Corruption. Washington.

Wright, P./Ferris, S.P./Sarin, A./Awasthi, V. (1996): Impact of Corporate Insider, Blockholder, and Institutional Equity Ownership on Firm Risk Taking, in: The Academy of Management Journal, 39, 2, 441-463. 
Zupan, N./Farčnik, D./Fišer, J./Stančič Kodarin, L./Valenčič, G. (2010): Investment in People and Organizational Flexibility in Slovenian Manufacturing Firms in 2006-2009, in: Prašnikar, J. (ed.): The role of intangible assets in exiting the crisis. Ljubljana: Časnik Finance. 